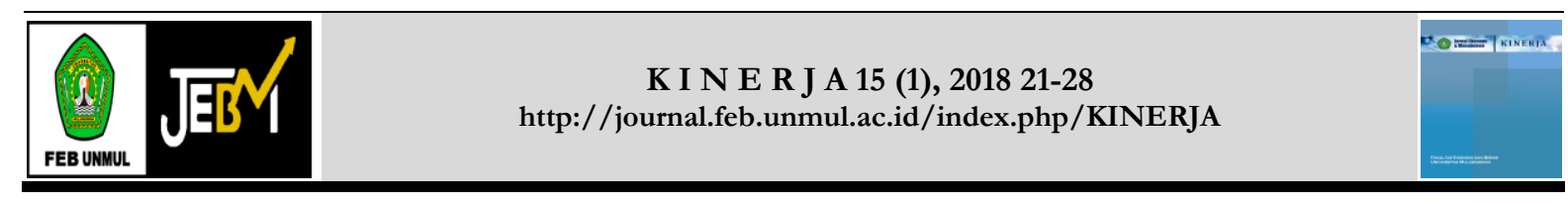

\title{
Pengaruh manajemen aktiva terhadap laba
}

\author{
Parel Christian$^{1}$, Ardi Paminto², M. Amin Kadafi ${ }^{3}$ \\ Fakultas Ekonomi dan Bisnis Universitas Mulawarman, Samarinda. \\ ${ }^{1}$ Email: parel.christian@mhs.feb.unmul.ac.id \\ ${ }^{2}$ Email: ardi.paminto@feb.unmul.ac.id \\ ${ }^{3}$ Email: muhammad.amin.kadafi@feb.unmul.ac.id
}

\begin{abstract}
Abstrak
Tujuan penelitian ini adalah untuk mengetahui pengaruh manajemen aktiva terhadap laba PT Bahtera Indah Jaya Cabang Samarinda ditinjau dari rasio aktivitas dan Profitabilitas. Penelitian ini menggunakan metode deskriptif, yaitu melakukan penilaian serta pengukuran terhadap angka-angka dalam laporan keuangan yang meliputi laporan neraca dan laba rugi pada tahun 2012 sampai dengan tahun 2014. Berdasarkan perhitungan pada rasio aktivitas menunjukan bahwa kondisi perusahaan yang kurang baik, karena nilai fixed assets turn over dan total assets turn over berfluktuasi kecenderungan mengalami penurunan. Rasio profitabilitas menunjukan kemampuan perusahaan dalam menghasilkan keuntungan terlihat kurang baik, karena nilai profit margin, return on assets dan return on equity berfluktuasti dengan kecenderungan mengalami penurunan pada dua tahun terakhir yaitu pada tahun 2013 dan 2014.
\end{abstract}

Kata Kunci: rasio aktivitas; profitabilitas

\section{Effect of asset management on earnings}

\begin{abstract}
The purpose of this study was to determine the effect of the asset management profit PT Bahtera Indah Jaya Branch Samarinda in terms of activity and profitability ratios. This research uses descriptive method, that the assessment and measurement of the figures in the financial statements that include the balance sheet and profit and loss in 2012 to 2014. Based on the calculation of the ratio of activity indicates that the condition of the company is not good, because the value of fixed assets turn over and turn over total assets decreased tendency to fluctuate. Profitability ratio shows the company's ability to generate profits look less good, because the value of profit margin, return on assets and return on equity berfluktuasti with a tendency to decline in the last two years, namely in 2013 and 2014.
\end{abstract}

Keywords: activity ratio; profitability 


\section{PENDAHULUAN}

Didirikannya suatu perusahaan memiliki suatu tujuan yang jelas yaitu untuk mencapai keuntungan yang maksimal atau laba yang sebesar-besarnya dan memakmurkan pemilik perusahaan. Bagi pengelola perusahaan, tentu ingin mengetahui apakah perusahaan yang dikelola selama ini telah berjalan dengan baik. Untuk mengetahui apakah perusahaan sudah berjalan degan baik, maka pengelola harus mengetahui kinerja perusahaan yang dikelolanya.

PT Bahtera Indah Jaya merupakan suatu perusahaan yang bergerak dalam bidang usaha kontraktor. Sebagai suatu unit bisnis yang dalam aktivitasnya senantiasa bertujuan untuk memperoleh keuntungan atau laba yang optimal bagi Perusahaan PT Bahtera Indah Jaya. Maka sudah selayaknya manajemen memikirkan strategi yang dapat meningkatkan kemampuan perusahaan dalam memperoleh laba dengan aktiva yang dimiliki PT Bahtera Indah Jaya. Maka dalam hal ini manajemen maupun pihak-pihak terkait perlu memperhatikan apakah tujuan perusahaan untuk memperoleh laba maupun pengelolaan aktivanya telah berjalan dengan baik dan efektif.

Aktiva tetap adalah salah satu elemen utama dari kekayaan perusahaan kontraktor yang berjumlah besar dan aktiva tetap ini akan selalu mengalami penyusutan dalam satu periode. Menurut Mulyadi (2002:179) Aktiva tetap adalah "Kekayaan perusahaan yang memiliki wujud, mempunyai manfaat ekonomis lebih dari satu tahun, dan diperoleh perusahaan untuk melaksanakan kegiatan perusahaan, bukan untuk dijual kembali”.

Manajemen aktiva dapat diartikan sebagai pengelolaan pada perusahaan, baik aktiva lancar maupun aktiva tetap. Menurut Home dan Wachowiez (2005:4),

menyebutkan bahwa manajemen aktiva adalah salah satu keputusan dalam perusahaan. Jika aktiva telah diperoleh dan pendanaan yang tepat telah tersedia, aktiva-aktiva yang ada tetap memerlukan pengelolaan yang efektif dan efisien.

Laba merupakan elemen yang paling menjadi perhatian pemakai karena angka laba diharapkan cukup kaya untuk merepresentasi kinerja perusahaan secara keseluruhan. Akan tetapi, teori akuntansi sampai saat ini belum mencapai kemantapan dalam pemaknaan dan pengukuran laba. Oleh karena itu, berbeda dengan elemen statemen keuangan lainnya.

\section{Kajian Pustaka}

\section{Manajemen Keuangan}

\section{Pengertian Manajemen Keuangan}

Manajemen keuangan merupakan suatu alat yang sangat penting untuk memperoleh informasi sehubungan dengan posisi keuangan dan hasil-hasil yang telah dicapai oleh perusahaan. Adapun manajemen keuangan menurut Horne dan Wachowicz (2002:2) menyebutkan sebagai berikut "Financial management is concerned with acquisition, financing, and management of assets with some overall goal in mind". Pengertian tersebut dapat diambil kesimpulan bahwa manajemen keuangan berkaitan dengan perolehan, pendanaan, dan manajemen aktiva untuk mencapai tujuan yang menyeluruh.

Selanjutnya menurut Martono dan Harjitno (2002:4) adalah sebagai berikut "Manajemen keuangan atau dalam literatur lain disebut pembelanjaan adalah segala aktivitas perusahaan yang berhubungan dengan bagaimana memperoleh dana, menggunakan dana dan mengelola asset sesuaidengan tujuan perusahaan secara menyeluruh".

\section{Tuiuan dan Fungsi Manajemen Keuangan}

Tujuan manajemen keuangan menurut Gitosudarmo dan Basri (2002:7) adalah untuk meningkatkan nilai (value) perusahaan dengan meningkatkan nilai saham dan peningkatan nilai perusahaan. Menurut Sundjaja dan Barlian (2003:67) tujuan manajemen keuangan adalah Selalu memaksimalkan laba. Untuk mencapai tujuan dari memaksimalkan laba, manajer keuangan hanya mengambil tindakan yang diharapkan dapat memberikan kontribusi utama untuk keseluruhan laba perusahaan.

Fungsi manajemen keuangan terdiri dari tiga keputusan utama yang harus dilakukan oleh setiap perusahaan yaitu.

Keputusan lnvestasi, berkaitan dengan jumlah aktiva yang dimiliki, kemudian penempatan komposisi masing-masing aktiva 
Keputusan pendanaan, merupakan keuputusan yang berkaitan dengan jumlah pendanaan yang disediakan perusahaan, baik yang bersifat utang atau modal sendiri.

Keputusan manajemen aktiva, hal ini berkaitan dengan pengelolaan aktiva secara efisien, terutama dalam hal aktiva lancar dan aktiva tetap.

\section{Laporan Keuangan}

Laporan keuangan dibuat dengan maksud untuk memberikan gambaran atau laporan kemajuan yang secara periodik dilakukan pihak manajemen perusahaan yang bersangkutan. Laporan keuangan menurut Kasmir (2010:66) adalah "Laporan yang menunjukkan kondisi keuangan perusahaan pada saat ini atau dalam suatu periode tertentu". Sedangkan menurut Riyanto (2001:327), mengartikan laporan keuangan sebagai berikut "Laporan keuangan (financial statement) memberikan ikhtisar mengenai keadaan finansial suatu perusahaan, dimana neraca (balance sheet) mencerminkan nilai aktiva, hutang dan modalsendiri pada suatu saat tertentu dan laporan laba rugi (income statement) mencerminkan hasilhasil yang dicapai selama suatu periode tertentu biasanya meliputi satu tahun".

Selanjutnya menurut Baridwan (2004:3) tujuan laporan keuangan adalah

Menyediakan informasi yang menyangkut posisi keuangan, kinerja, serta perubahan posisi keuangan suatu perusahaan yang bermanfaat bagi sejumlah besar pemakai dalam pengambilan keputusan ekonomi.

Laporan keuangan biasanya terdiri dari:

Neraca yaitu laporan keuangan utama yang memberikan informasi tentang posisi keuangan pada suatu saat menyajikan dua pokok aktiva maupun

passiva atau dengan kata lain neraca merupakan laporan yang memberikan

informasi mengenai jumlah harta, utang dan modal perusahaan pada suatu saat tertentu.

Pengertian neraca menurut Astuti (2004:19) adalah laporan posisi keuangan perusahaan pada waktu tertentu. Sisi kiri neraca menunjukkan aktiva perusahaan, sedangkan sisi kanan neraca menunjukkan kewajiban dan ekuitas atau klaim terhadap aktiva tersebut. Sedangkan menurut Sutrisno (2009:9) mengemukakan pengertian neraca adalah Laporan yang menunjukkan suatu perusahaan pada saat tertentu. Neraca mempunyai dua sisi, sisi debit dan sisi kredit. Pada sisi debit menunjukkan posisi kekayaan perusahaan (aktiva) yang terdiri dari aktiva lancar dan aktiva tetap.

Laporan Laba Rugi, yaitu laporan yang menunjukkan hasil usaha dan biaya-biaya selama periode tertentu. Menurut Munawir (2002:26) Laporan Laba Rugi merupakan suatu laporan yang sistematis tentang penghasilan, biaya, laba rugi yang diperoleh oleh suatu perusahaan selama periode tertentu.

Bridwan (2004:29) laporan laba rugi adalah suatu laporan yang menunjukan pendapatanpendapatan dan biaya-biaya dari suatu unit usaha untuk suatu periode tertentu.

Menurut Astuti (2004: 19) laporan laba rugi adalah sebagai berikut:

"Laporan yang mengikhtiarkan pendapatan dan beban perusahaan selama periode akuntansi tertentu, yang umumnya setiap kuartal atau setiap tahun.

\section{Analisis Laporan Keuangan}

Analisis laporan keuangan dapat memaksimalkan informasi yang masih relatif sedikit menjadi informasi yang lebih luas dan akurat. Hasil analisi laporan keuangan dapat membuktikan berbagai masalah dari suatu laporan. Menurut Munawir (2004 : 35), menjelaskan bahwa "Analisa-analisa laporan keuangan terdiri dari penelaan atau mempelajari daripada hubungan-hubungan dan tendensi atau kecenderungan (tren) untuk menentukan posisi keuangan dan hasil operasi serta perkembangan perusahaan yang bersangkutan".

\section{Tujuan Analisis Laporan Keuangan}

Dalam setiap perusahaan analisis laporan keuangan sangat penting karena tujuan analisis laporan keuanagan adalah untuk menyederhanakan data- data keuangan suatu perusahaan sehingga dapat dimengerti. Dalam menganalisis laporan keuangan suatu perusahaan harus dilakukan pengorganisir atau mengumpulkan suatu data yang diperlukan, mengukur dan mengasa laporan tersebut sehingga lebih menjadi berarti.

\section{Analisis Rasio Keuangan (Financial Ratio Analysis)}

Mengadakan analisis hubungan dari berbagai pos dalam suatu laporan keuangan merupakan dasar untuk dapat menginterpretasikan kondisi keuangan dan hasil operasi suatu perusahaan. 
Syamsuddin (2004:37) mendefinisikan analisis rasio keuangan adalah "Perhitungan rasio-rasio untuk menilai keadaan keuangan perusahaan di masa lalu, saat ini dan kemungkinan di masa depan yang akan datang". Menurut lrawati (2006:22) menyatakan bahwa "Rasio keuangan merupakan suatu teknik analisis dalam bidang manajemen keuangan yang dimanfaatkan sebagai alat ukur kondisikondisi keuangan suatu perusahaan dalam periode tertentu, ataupun hasil-hasil usaha dari suatu perusahaan pada satu periode tertentudengan jalan membandingkan dua variabel yang diambil dari laporan keuangan perusahaan, baik daftar neraca maupun rugi-laba."

Sedangkan menurut Jumingan (2006:118) analisis rasio keuangan adalah Angka yang menunjukkan hubungan antara suatu unsur dengan unsur lainnya dalam laporan keuangan. Hubungan antara unsur-unsur laporan keuangan tersebut dinyatakan dalam bentuk matematis sederhana. Selanjutnya Manahan (2005:35) memberikan pengelompokan rasio keuangan yakni Rasio likuiditas, Rasio Pengungkit, Rasio efesiensi, Rasio profitabititas

\section{Manajemen Aktiva}

Manajemen aktiva atau aset melihat bagaimana mengukur kemampuan perusahaan dalam menggunakan dana yang tersedia yang tercermin dalam perputaran aktivanya. Manajemen aktiva dapat diartikan sebagai pengelolaan pada perusahaan, baik aktiva lancar maupun aktiva tetap.

Menurut Home dan Wachowiez (2005:4), menyebutkan bahwa "Manajemen aktiva adalah salah satu keputusan dalam perusahaan. Jika aktiva telah diperoleh dan pendanaan yang tepat telah tersedia, aktiva-aktiva yang ada tetap memerlukan pengelolaan yang efisien. Manajer keuangan bertanggung jawab terhadap aktiva-aktiva yang ada". Sedangkan menurut Weston dan Copeland (2010:247) menyatakan bahwa "Manajemen Aktiva dan lnvestasi (Assef dan lnvestment Management) adalah mengukur efektifitas keputusan- keputusan investasi perusahaan dan pemanfaatan sumber dayanya".

\section{Aktiva Lancar}

Aktiva Lancar didefinisian sebagai aktiva yang secara normal berubah menjadi kas dalam waktu satu tahun atau kurang. Manajemen modal kerja biasanya menyangkut pengelolaan aktiva-aktiva ini dan pengelolaan aktiva lancar. Sedangkan pengelolaan aktiva tetap, yaitu aktiva yang berubah menjadi kas memerluhkan waktu lebih dari satu tahun, biasanya di sebut sebagai capital budgeting.

\section{Strukur Jangka Waktu Pendanaan}

Apabila diasumsikan bahwa telah mempunyai kebijaksanaan tentang pembayaraan dan pembeliaan (tunai atau kredit, kalau kredit berap lama akan dilunasi), pembayaran upah atau gaji, serta pembayaran pajak dan biaya-biaya lain.

Pendekatan hedging, Strategi pendanaan ini membiayai setiap aktiva dengan dana yang jangka waktunya kurang lebih sama dengan jangka waktu perputaran aktiva tersebut menjadi kas. Dengan demikian, variasi jangka pendek aktiva lancar akan dibiayai dengan hutang jangka pendek, Komposisi permanen aktiva lancar akan dibiayai dengan hutang jangka panjang atau modal sendiri, demikian pula untuk aktiva tetap.

Pendanaan jangka pendek dan jangka panjang sangat sulit memperkirakan kapan suatu aktiva akan berubah menjadi kas dan kapan pembayaran finansia. Dengan demikian penentuan jangka waktu menjadi sangat penting untuk menghindarkan perusahaan dari kesulitan keuangan (likuiditas).

\section{Jumlah Aktiva Lancar}

Seandainya perusahaan telah menetapkan kebijaka piutang dan persediaan, maka jumlah aktiva lancar, disamping dipengaruhi oleh tingkat operasi perusahaan juga akan dipengruhi oleh besar kecinya perusahaan menyediakan kas(aktiva likuid). Untuk tingkat operasi yang sama, semakin besar aktiva likuid yang diediakan, semakin besar jumlah aktiva lancar yang dimiliki.

\section{Aktiva Tetap}

Aktiva tetap merupakan aktiva jangka panjang atau relatif permanen seperti peralatan, tanah bangunan, gedung yang digunakan oleh perusahaan untuk membantu atau menunjang operasi perusahaan dalam menghasilkan barang atau jasa. Menurut Mulyadi (2007:153) menjelaskan bahwa: "Aktiva tetap adalah aktiva berwujud yang digunakan dalam operasi perusahaan dan tidak dimaksudkan untuk dijual dalam rangka kegiatan normal perusahaan". 


\section{Jenis-Jenis Aktiva Tetap}

Aktiva tetap memiliki beragam jenis, bentuk dan umur manfaat, ada aktiva tetap yang umurnya tidak terbatas serta ada aktiva tetap yang umumya terbatas. Aktiva tetap yang umumya terbatas seperti kendaraan, sedangkan aktiva tetap yang umumya tidak terbatas adalah tanah. Menurut Baridwan (2005:287), mengemukakan jenis-jenis aktiva tetap terdiri dari Tanah, bangunan, mesin dan alat-alat, alat-alat kerja, pattem dan dieslcetakan-cetakan, perabot dan alat-alat kantor, kendaraan, tempat barang yang dapat dikembalikan. Sedangkan menurut Warren, et al (2005:504) jenis-jenis aktiva tetap terdiri dari Peralatan, Perabotan, Alat-alat, Mesin-mesin, Bangunan dan Tanah.

\section{Karakteristik Aktiva Tetap}

Menurut Simamora (2003:298), mengemukakan bahwa aktiva tetap dapat dibedakan dari aktiva-aktiva lainnya berdasarkan karakteristik-karakteristik berikut:

Aktiva tetap diperoleh untuk dipakai dalam kegiatan-kegiatan usaha, Nilai dari suatu aktiva tetap berdasarkan dari jasa yang diberikannya, bukan dari potensinya untuk dijual kembali. Perusahaan membeli aktiva tetap untuk digunakan dalam kegiatan-kegiatan bisnisnya

Aktiva tetap menyediakan manfaat selama beberapa periode akuntansi, Menurut prinsip hubungannya, biaya perolehan dari suatu sumber daya

yang rnemberikan suatu potensi jasa haruslah dikaitkan dengan beban

untuk menghasilkan jasa tersebut.

Sedangkan Menurut Warren, et al (2005:504), yang diterjemahkan oleh Farahmita, dkk berpendapat bahwa yang menjadi karakteristik aktiva tetap adalah: "Mereka merupakan aktiva tetap berwujud (tangible assets) karena terlihat secara fisik. Aktiva tersebut dimiliki dan digunakan oleh perusahaan serta tidak dimaksudkan untuk dijual sebagian dari operasi normal".

\section{Biaya Perolehan dan Penyusutan Aktiva Tetap}

Biaya perolehan aktiva tetap meliputi semua jumlah yang dikeluarkan untuk mendapatkan aktiva tetap dan memuatnya siap digunakan. Tanah memiliki usia yang tidak terbatas dan dengan demikian mampu memberikan manfaat yang tidak terbatas. Sementara itu aktiva lainnya seperti peralatan, bangunan, dan pengembangan tanah (land improvement) akan kehilangan kemampuan mereka seiring dengan berlalunya waktu, untuk menyediakan manfaat kepada perusahaan. Karenanya, biaya peralatan, bangunan, dan pengembangan tanah harus ditransfer ke akun beban dengan cara yang sistematis sepanjang umur manfaatnya. Transfer periodik ini, dari biaya ke beban dinamakan dengan penyusutan atau depresiasi. Waren, et al(2005: 495).

sampingan atau transaksi yang jarang terjadi dari suatu badan usaha, dan dari semua transaksi atau kejadian lain yang mempunyai badan usaha selama satu priode, kecuali yang timbul dari pedapatan (revenue) atau investasi pemilik (Baridwan,1992:55). Laba sering digunakan sebagai suatu dasar untuk pengenaan pajak, kebijakan deviden, pedoman investasi serta penggambilan keputusan dan unsur prediksi (Hartono, 2003:444).

Pengukuran laba bukan saja penting untuk menentukan prestasi perusahaan tetapi penting juga penting sebagai informasi bagi pembagian laba dan penentuan kebijakan investasi. Oleh kerena itu, Laba menjadi informasi yang dilihat oleh banyak seperti profesi akuntansi, Pengusaha, Analisi keuangan, Ekonom, Fiskus, dan sebagainya (Harahap, 2001:259). (https://kelompoklaba.wordpress.com)

\section{METODE}

\section{Definisi Oprasional}

PT Bahtera Indah Jaya Cabang Samarinda merupakan objek penelitian yang bergerak dibidang Kontraktor. Sebagai perusahaan yang selalu mengedepankan efisien dan efektivitas kinerja maka sangat diperlukan analisis laporan keuangan.

Rasio Aktivitas merupakan perhitungan untuk menentukan aktivitas dari kelas tertentu dari aktiva dan mengukur efektivitas manajemen dalam mengunakan dan mengendalikan aktiva tersebut. Adapun indikator yang digunakan dalam rasio ini yaitu fixed assets turnover dan total assets turnover.

Rasio Profitabilitas merupakan rasio yang mengukur efektivitas manajemen perusahaan secara keseluruhan yang ditunjukkan oleh besar kecilnya tingkat keuntungan yang diperoleh dalam 
hubungannya dengan penjualan maupun investasi. Adapun Indikator variable yang digunkan dalam rasio Rentabilitas ini adalah Profit Margin, Return on Equity (ROE), Return On Total Assets (ROA).

\section{Metode Kepustakaan}

Penelitian kepustakaan dilakukan dengan menbaca buku-buku pustaka, referensi dan sebagainya agar dapat memperoleh pengetahuan tentang yang diteliti, sehingga dapat memecahkan masalah penelitian dengan cepat dan tepat. Dalam penelitian kepustakaan ini data yang diambil berasal dari jurnal-jurnal yang berkaitan dengan skripsi yang diteliti oleh penulis, buku-buku literatur dan penelitian sejenis.

\section{HASIL DAN PEMBAHASAN}

\section{Aktivitas PT Bahtera Indah Jaya2012 Sampai Dengan Tahun 2014.}

Nilai rasio aktivitas akan menjelaskan tingkat kemampuan PT Bahtera Indah Jaya dalam mengefisienkan seluru asset yang dimiliki dalam menghasilkan pendapatan. Tingkat aktivitas PT Bahtera Indah Jaya dalam penelitian ini akan dilihat dari dua jenis rasio yang terdiri dari Fixed assets turn over dan total assets turn over.

Nilai Fixed assets turn over PT Bahtera Indah Jaya pada tahun 2012 adalah 0,82 kali, tingkat perputaran aktiva tetap mengalami penurunan pada tahun 2013 menjadi 0,76 nilai ini turun sebesar 0,06 kali dari tahun sebelumnya. Nilai rasio yang menurun disebabkan nilai penjualan perusahaan dari Rp 12.159.570.000 pada tahun 2012 menjadi Rp 11.213.650.000 pada tahun 2013 meskipun terjadi penurun pada aktiva tetap. Akan tetapi penurunan pada volume penjualan lebih besar. Perputaran aktiva tetap pada tahun 2014 mengalami peningkatan menjadi 0,85 kali nilai ini naik sebesar 0,09 kali.

Kenaikan ini terjadi karena meningkatnya nilai penjualan perusahaan menjadi Rp 12.730.710.000. Semakin tinggi tingkat perputaran aktiva tetap maka semakin baik menunjukan efektivitas dalam penggunaan aktiva tetapnya.

Nilai Total Assets Turn Over PT Bahtera Indah Jaya pada tahun 2012 sebesar 0,58 kali. Tingkat perputaran total aktiva pada tahun 2013 turun menjadi 0,54 kali, nilai ini turun sebesar 0,04 kali dari tahun sebelumnya. Penurunan nilai total assets turn overterjadi karena nilai penjualan perusahaan yang kembali mengalami penurunan, nilai penjualan perusahaan pada tahun 2013 sebesar Rp 11.213.650.000. Total assets turn over PT Bahtera Indah Jaya tahun 2014 naik menjadi 0,59 kali, nilai ini naik sebanyak 0,05 kali dari tahun 2013. Kenaikan ini terjadi karena meningkatnya nilai penjualan perusahaan dari Rp 11.213.650.000 pada tahun 2013 menjadi Rp 12.730.710.000 pada tahun 2014. Hal ini mengambarkan bahwa perusahaan mampu dalam mengefektifkan total asetnya pada tahun terakhir.

\section{Profitabilitas PT Bahtera Indah Jaya 2012 Sampai Dengan Tahun 2014.}

Nilai dari rasio profitabilitas akan menggambarkan tingkat kemampuan PT Bahtera Indah Jaya dalam menghasilkan keuntungan bagi perusahaan. Tingkat profitabilitas perusahaan PT Bahtera Indah Jaya dalam penelitian ini akan dilihat dari tiga jenis rasio profitabilitas yang terdiri dari: profit margin, return on assets dan return on equity. Hasil perhitungan dari rasio-rasio profitabilitas perusahaan PT Bahtera Indah Jaya akan diuraikan lebih lanjut pada bagian dibawah ini.

Profit margin pada tahun 2012 sebesar 14,39\% yang berarti setiap Rp 1,00 penjualan perusahaan mampu menghasilkan laba operasi sebesar Rp 0,1439. Profit margin pada tahun 2013 sebesar 14,95\% atau $\mathrm{Rp} 0,1495$. Hal ini berarti bahwa setiap $\mathrm{Rp} 1,00$ penjualan perusahaan mampu menghasilkan laba operasi Rp 0,1495. Profit margin pada tahun 2014 sebesar 14,83\% yang berarti setiap Rp 1,00 penjualan perusahaan mampu menghasilkan laba operasi sebesar Rp 0,1483. Profit margindari tahun 2012 sampai 2014 mengalami fluktuasi dengan kecenderungan mengalami penurunan pada tahun terakhirnya. Menurunnya nilaI profit marginI pada tahun 2014 menunjukkan bahwa perusahaan tidak memiliki kemampuan dalam memperoleh laba. Hal ini disebabkan peningkatan pada EAT atau laba setelah pajak lebih kecil dari pada peningkatan yang terjadi pada penjualan perusahaan.

Return on Asset tahun 2012 sebesar 8,45\% dari hasil analisi yang dilakukan rasio ini mengalami penurunan sebesar 0,28\% di tahun 2013 Return on Asset pada tahun 2013 sebesar 8,17\% . Hal ini disebabkan laba sebelum pajak mengalami penurunan pada tahun $2012 \mathrm{Rp} 1.755 .447 .464$ menjadi $\mathrm{Rp}$ 1.671.762.671 pada tahun 2013. Return on Asset pada tahun 2014 sebesar 8,8\% atau naik sebesar 
$0.63 \%$ dari tahun sebelumnya. Hal ini mengambarkan bahwa perusahaan mampu menghasilkan laba dengan semua aktiva yang dimiliki oleh perusahaan di tahun terakhir, Meskipun Return on Asset mengalami penurunan pada tahun sebelumnya yaitu pada tahun 2013.

Return on equity pada tahun 2012 sebesar 9,6\%, hal ini berarti setiap rupiah modal sendiri menghasilkan keuntungan bersih Rp 0,96. Return on equity pada tahun 2013 sebesar 9,31\%, atau turun sebanyak $0,29 \%$ dari tahun sebelumnya. Hal ini disebabkan menurunnya laba bersih dan modal sendiri pada tahun 2013. Nilai return on equity pada tahun 2014 mengalami peningkatan sebesar $0,98 \%$ menjadi 10,29\%. Return on equity selama tahun 2012 sampai tahun 2014 mengalami fluktuasi dengan kecenderungan mengalami penurunan pada tahun 2013. Meskipun demikian nilai return on equity pada tahun terakhir menggambarkan kinerja perusahaan mengalami peningkatan, hal ini ditunjukan dengan kenaikan laba bersih dan modal sendiri pada tahun terakhir.

\section{SIMPULAN}

\section{Aktivitas}

Dari perhitungan rasio aktivitas selama tiga tahun terakhir dari tahun 2012 sampai tahun 2014 dengan rasio fixed assets turn over dan total assts turn over. Berdasarkan perhitungan pada perputaran aktiva tetap (fixed assets turn over) dari tahun 2012 sampai tahun 2014 berfluktuasi atau naik turun pada satu tahun yaitu pada tahun 2013. Hal ini menunjukan bahwa kinerja perusahaan dalam pengelolaan aset tetapnya belum stabil. Hal yang sama juga terjadi pada perhitungan tingkat perputaran total aktiva (total assets turn over) dari tahun 2012 sampai tahun 2014 berfluktuasi dengan kecenderungan mengalami penurunan pada tahun 2013. Meskipun nilai perputaran total aktiva perusahaan naik pada tahun terakhir. Hal ini menggambarkan bahwa perusahaan belum mampu mempertahankan kemampuannya dalam mengefektifkan total aset yang dimiliki. Aktivitas perusahaan yang terlihat dalam perhitungan rasio aktivitas menunjukan bahwa kondisi aktivitas PT Bahtera Indah Jaya kurang baik, karena rasio yang berfluktuasi dengan kecenderungan mengalami penurunan pada tahun 2013.

\section{Profitabilitas}

Dari perhitungan rasio profitabilitas selama tiga tahun terakhir 2012, 2013 dan 2014 dengan rasio profit margin, return on assets dan return on equity cenderung berfluktuasi. Berdasarkan perhitungan pada profit margin pada tahun 2012 dan 2013 terjadi peningkatan kemudian pada tahun 2014 terjadi penurunan. Terjadinya fluktuasi pada profit margin pada tahun 2014 disebabkan karena besarnya peningkata terjadi pada penjualan meskipun EAT atau laba setelah pajak mengalami peningkatan. Sedangkan perhitungan pada return on assets pada tahun terakhir mengalami peningkatan, karena terjadinya peningkatan laba yang selalu dapat diimbangi oleh peningkatan total aktiva. Hal ini berarti kemampuan perusahaan dalam meningkatkan laba di tahun terakhir mengalami peningkatan dan menunjukkan kemampuam perusahaan dalam mencapai keuntungan dari aktiva yang dimiliki. Kemudian pada return on equity mengalami peningkatan pada tahun terakhir hal ini disebabkan terjadinya peningkatan pada laba bersih dan kemudian diimbangi dengan modal sendiri.

\section{Hubungan Manajemen Aktiva terhadap Laba}

Hubungan manajemen aktiva terhadap laba PT Bahtera Indah Jaya pada tahun penelitian berfluktuasi atau naik turun, Hal ini dapat dilihat dari rasio aktivitas dan rasio profitabilitas. Hasil penenlitian menunjukan bahwa manajemen aktiva berpengaruh dalam peningkatan laba maupun dalam mengefetifkan pengelolaan aset yang dimiliki.

\section{DAFTAR PUSTAKA}

Astuti, Dewi. 2004. Manajemen Keuangan Perusahaan, Edisi Pertama. Penerbit.Ghalia Indonesia.

Baridwan, Zaki .2004. Intermediate Accounting, Edisi Kedelapan, Cetakan Pertama, BPFEYogyakarta.

Brigham, Eugene F. Dan Joel F. Houston, 2009. Dasar-dasar Manajemen Keuangan, Buku Satu, Edisi Kesepuluh, Ahli Bahasa Ali Akbar Yulianto. Jakarta: Selemba Empat

Gitosudarmo, Indriyo dan Basri, 2002. Manajemen Keuangan, Edisi Keempat, BPFE UGM, Yogyakarta. 
Harahap, Sofyan Syafri, 2010. Analisis Laporan Keuangan, Edisi Kesatu, Cetakan Kesembilan, Raagrafindo Persada, Jakarta.

Irawati, Susan, 2006. Manajemen Keuangan, Cetakan Pertama, Pustaka, Bandung.

Jumingan, 2006. Analisis Laporan Keuangan, Cetakan Pertama, PT Bumi Aksara, Jakarta.

Kasmir, 2010. Pengantar Manajemen keuangan, Edisi Pertama. Kencana Prenada Media Grup. Jakarta.

Manahan, 2005. Manajemen Keuangan (Financi Management), Cetakan Pertama, Ghalia Indonesia, Bogor.

Martono SU,D, Agus Harjitno, 2002. Manajemen Keuangan, Edisi Pertama, Ekonisia, Yogyakarta.

Mulyadi, 2007. Sistem Perencanaan dan Pengendalian Manajemen, Penerbit Salemba Empa, Yogyakarta.

Munawir. 2007, Analisis Laporan Keuangan. Edisi keempat. Penerbit. Liberty, Yogyakarta.

Riyanto, Bambang. 2001. Dasar-Dasar Pembelajaan Perusahaan. Edisi keempat. Cetakan Ketujuh, BPFE-Yogyakarta.

Simamora, Henry, 2003. Akuntansi Manajemen, Salemba Empat, Jakarta. Sutrisno. 2009. Manajemen Keuangan (teori,Konsep dan aplikasi. Edisi Pertama.

Cetakan ketujuh. Penerbit Ekonisia Kampus Fakultas Ekonomi Yogyakarta.

Sundjaja, R,S, dan Barlian, Inge, 2003. Manajemen Keuangan I, Edisi Kelima, Literata Lintas Media, Jakarta.

Syamsuddin, Lukman, 2004. Manajemen Keuangan Perusahaan, (Konsep Aplikasi dalam Perencanaan, Pengawasan dan pengambilan Keputsan), Cetakan Kedelapan, Rajagrafindo Persada, Jakarta.

Van Home, James C And Wachowiez, John M, JR, 2002. Fudamental of Financial Management, Partice Hall, Inc. New Jersey.

Waren,et al, 2005. Pengantar Akuntansi 1, Edisi 21, Selamba Empat, Jakarta. Weston, J.Fred, Copeland, Thomas.E, 2010. Manajemen Keuangan, Bina Rupa Aksara, Tangerang. 